\title{
Analysis on The Impact of Financial Crisis against China's Export
}

\author{
ZHANG Rui \\ Jilin Business and Technology College P.R.China,130000 \\ 33388960@qq.com
}

Key words: financial crisis; export; influence

\begin{abstract}
Our country is a highly dependent on the development of foreign trade country, export trade always in the economic development of our country occupies a important position, after the financial crisis, economies around the world appear continued to slide, under the influence, China's exports fell sharply, economic growth rate slowed down. Therefore, this paper mainly analyzes the positive and negative effects of financial crisis on China's foreign trade, focusing on the three aspects of the government, foreign trade enterprises, industry associations to deal with the financial crisis.
\end{abstract}

\section{Introduction}

Forcing China's foreign trade from extensive growth to the rational and sustainable development stage. China, as a developing country, is different from the economic development of a small country. It can not achieve long-term economic development through the export oriented strategy. Because a country economic growth the prerequisite on the long-term stability of the external demand growth foundation, which in itself is very fragile, if the oscillations in the international market, China's import and export trade even growth of the national economy will be subject to serious blow. According to the American scholar Chanari's research on the mode of development of big country and small country's development model, it is concluded that the main characteristics of the development of great powers should be the low level of international trade. The greater the country, the stronger the inward nature of its policy. In the transition period, the export volume of a typical big country should only account for $12 \%$ of the gross national product. And China has more than 20 years ago this standard, and long-term export oriented strategy to promote export dependence from 2003 has begun more than 30\%. And the crisis will be the international economic risks of China's extensive growth in imports and exports has become a reality. Therefore, when the crisis led to the scale of export trade rapidly decreases, we should not only think about how to restore the previous peak period of trade, but should reflect on our import and export extensive growth mode, has been with the development of China's economy comes to an end. Therefore, it can be predicted that after the crisis, if you want to in the international trade market still occupies an important position, China should change the growth mode of foreign trade, change our traditional established under the social security system is lack of cheap labor advantage path and trade development emphasis placed on how to improve the product "the competitiveness of China".

Promoting the diversification of China's foreign trade market. China's foreign trade market too concentrated in the United States, the European Union and Japan and other developed countries and regions, and of these trading partners over reliance on has been the potential risk to our country foreign trade development, in the economic crisis, the United States, Europe, Japan and other 
countries suffered the most serious impact of recession quickly, so the demand for Chinese exports must greatly decline. Due to the emerging markets and developing countries relatively suffer from the impact of the financial crisis lighter, external demand market size is also relatively stable. Therefore, crisis will enable China to reduce dependence on developed countries in foreign trade export, and then turned to the emerging market countries in the market development demand. Although the adjustment of pressure and open up new markets is very difficult, but after a painful transformation, distribution of China's foreign trade market in the global range will tend to a reasonable and rational, which will also be greatly enhanced resistant to the future of China's foreign trade and international economic risk ability.

The trade structure between general trade and processing trade is balanced. For a long time, China is committed to developing processing trade, its total trade volume accounted for more than half of the export trade. Processing trade can really bring the positive influence, China created a large number of foreign exchange earnings, but the pollution of the environment, easy to cause international trade friction, the added value of low negative effect problem is obvious, and the main shortcomings is to a great extent limits the upgrade of China's foreign trade commodities "the competitiveness of China". Since the financial crisis, due to the general trade of the domestic industry chain is relatively long, by the impact of the international financial crisis is relatively small. And processing trade against the fluctuation of the international market ability is poor, have a dramatic impact, its import and export amplitude decreased rapidly, the general trade development is obviously superior to the processing trade, the Chinese processing trade based trade structure imbalance are effectively corrected.

\section{The negative impact of financial crisis on China's exports}

Accelerating the transfer of international orders. Due to the reduction of China's export tax rebate and processing trade policy changes and other factors, China's manufacturing costs have been unable to undertake low-cost orders. The risk of international order transfer is increasing. If the tax rebate, the RMB exchange rate fluctuations or product quality problems, the enterprise will be a loss. China's manufacturing price advantage has gradually subsided, but foreign buyers will not put the eggs into one basket, will further pursue lower prices of products. They began to train suppliers in Vietnam, Kampuchea, Thailand, and other Southeast Asian countries to begin moving from China to Southeast Asian countries.

Increasing the risk of China's foreign trade settlement. International trade settlement usually by letter of credit, collection and remittance in three ways. The letter of credit is one of the most commonly used methods of payment in international trade, and the financial crisis has increased the risk of using it. In the case of the economic crisis, the collection risk for exporters will increase a lot. First, in the economic downturn period, the market downturn of the situation, many importers because of their funding chain, order volume shrinking, for captive to the loss and risk shifting to exporters, refused to extract the credit of the goods or took the opportunity to force exporters to lower the price. At this time, some of the issuing behavior preservation is likely to use their own expertise in the field of credit card settlement, with importers find false discrepancies to protest the purpose of enabling beneficiaries suffer losses further increase the risk. Also at the time of crisis, due to the uncertainty of the market, price trend elusive, demand is difficult to predict, importers (the applicant) also affected, let some open bank add restriction, uncertainty, unreasonable constraint clause in letter of credit, to later Payment or exemption from liability for payment of foreshadowing. 
External demand is declining, foreign trade enterprise profit decline. Our country's export commodities are mainly concentrated in the labor-intensive industries or the export of primary products, these enterprises in the international market is the low price to open and win the international market. But these enterprises are still stay at the stage of OEM production, the product is technical content is low, the added value of the products is very low in low-grade products, and these low-grade products is the price elasticity of demand higher products, price increases space is limited, in the international market in just the market price of the recipients. And China's foreign trade export enterprises because raw materials and primary products prices continued to rise, which can improve the production cost, but products in foreign demand and not through the price to cover the cost of the rise, profit space has been seriously squeezed. Since the outbreak of the financial crisis, the spending power of consumers in foreign countries a serious decline, reduced external demand, China's foreign trade export enterprises profit decline, slowdown in export growth, the trade surplus has declined, China's net export contribution to economic growth rate is reduced.

\section{Improving the financial crisis on China's foreign trade export negative effects of Countermeasures}

Optimize the structure of export products, improve products with high value-added content, optimize enterprise management. China is a country with abundant labor and resources. These advantages make the enterprises of our country produce low production cost, and can win in the international market competition at the time of export. And now, due to the impact of the financial crisis, raw materials and labor costs continue to increase, export enterprises should change the original concept, through science and technology research and development, technical innovation and other means to reduce added value, the production of high energy consuming products, optimize the structure of export products, in the face of the demand to develop with a large number of potential demand for new products, by the industrial chain in the lowest profit and processing sectors to develop high-end design, research and development, service and marketing, improve the entire industry profit margins and processing technology level and overall competitiveness. To accelerate industrial upgrading and enhance the quality and grade of the export commodities, improve digestion and absorption of foreign advanced technology and the capability of independent innovation in order to enhance product added value, realize from the "made in China" to "China to create a" beyond, enterprises should optimize the management, reduce production cost, enhance the international competitiveness of products.

Take government subsidies, export tax rebate policy. In the world many countries government to encourage the export of foreign trade enterprises are often formulated a number of policies and regulations to the relevant enterprises to take appropriate subsidies or export tax rebate to be economic support the reduce costs and burdens, keep the commodity in the international market price advantage. Export tax rebate is an international practice, but also in line with the requirements of the world trade organization, although it will be opposed by other countries, but also has been used in other countries. Financial crisis, foreign trade enterprises by the tremendous impact, the Chinese government should policy adjustments to ensure steady economic growth, increase support for small and medium-sized export enterprises, so as to ensure the stability of the foreign trade and employment. The government should also increase subsidies, taxes and policies on trade associations to give strong support to the industry association.

Trade associations do a good job of membership services. Foreign trade associations should actively participate in the development and reform of the industry, to play their own advantages, to grasp the industry trends, timely to provide the industry with the development of useful information. 
Industry associations should listen to the voice of the members and participate in research and formulation of the industry related to the interests of the government decision-making, urge relevant departments to support the introduction of corporate financing policy, tax collection and tax breaks for approval, such as policy, resulting in a more relaxed environment for the development to industry members. Also through the development of industry standards to protect the interests of the industry, so as to achieve the purpose of the government to protect the domestic market. Especially in the economic crisis to help enterprises get out of trouble as soon as possible, and the relevant government departments to actively communicate and promote the rapid development of enterprises, the formation of a win-win situation between enterprises and associations to promote.

\section{Conclusion}

Based on the above analysis, the impact of the financial crisis on China's exports larger, therefore, as a government, industry associations and enterprises have not shirk its responsibility to improve its existing problems, and actively respond to the negative impact of the financial crisis. Such as the Chinese government should encourage banks to financing foreign trade enterprises, strengthen international cooperation, to create a good environment for foreign trade, optimize the structure of foreign exchange reserves to stabilize the exchange rate, to take government subsidies, export tax rebate policy, increase government procurement; industry associations should foreign safeguard the interests of industry, strengthen its management of the building; enterprises export diversification strategy, do a good job in risk prevention of preparatory work.

\section{Reference}

[1] Huang Xianhai, Cai Wanting, Song Huasheng. The financial crisis and the change in the quality of exports: lipstick effect or forced to raise the issue of international trade [J]. 2015 (10)119-127.

[2] Yang Lianxing, Zhang Xiumin, Yao Chengfei. Study on the effect of heterogeneity on the quality of export and export price change -- a study of the microscopic evidence from the Chinese context [J]. world economic research. 2015 (09)109-116.

[3] Zhang Jie. Financial repression, financing constraints and export product quality [J]. financial research. 2015 (06) 111-115.

[4] Li Kun Wang, Jiang. Market entry and economic growth: An Empirical Analysis of China's manufacturing industry as an example [J]. economic research. 2015 (05)09-12. 